


\section{Mind the Gap! On the Discursive Construction of Collective Political Identities}

ARTICLE INFO:

Volume: 06

Issue: 02:2020

Month: March

ISSN: 2459-2943

DOI: 10.18680/hss.2020.0019

Pages: 11-27

Lic.: CC BY-NC-ND 4.0

KEYWORDS:

Political identities

Collective identities

Political discourse

Social Semiotics

Polarization
ABSTRACT

$\neg \Gamma$ his article explores, from a theoretical perspective, the dy1 namics underlying the discursive construction of collective identities within the political domain. Specifically, it: (1) presents a general mapping of political sphere studies carried out from a semiotic perspective; (2) attempts to bridge different paradigms within the semiotic tradition; and (3) establishes a dialogue between political theory and semiotics through the analysis of certain ideas belonging to the former whose semiotic nature has not yet been adequately examined, even if they are of a discursive nature. The article pays particular attention to the role that the 'political gap' - i.e., the space of indetermination between the various collective political identities that compete against each other in the 'contest over meaning' of politics - plays in the discursive construction of those identities. Arguing from a constructivist premise, establishing relational differences is a constitutive feature of the meaning-making, dynamic, and gaps between collective identities, a necessary precondition for their discursive emergence and the political sphere's existence.

\section{Introduction}

In the age of 'digitally networked participation' (Theocharis 2015), 'filter bubbles' (Pariser 2012), and growing symbolic violence online (Recuero 2015), several countries around the world have witnessed an increasing polarization in their political domains. This polarization, often characterized as distinctly 'affective' (Iyengar et al. 2012; Rogowski and Sutherland 2016), 
could be described as the subsumption of the actions and interactions comprising the political sphere under the premise of a radical distinction between and oppositional axiologization of an imagined positive 'We' and a negative 'They.'

Affective polarization has dangerous repercussions for democratic politics. Besides transposing the political debate from a rational to an emotional dimension, it fosters uncivil, fanatical, and even extremist attitudes and behavior. A whole range of questions regarding this phenomenon's logic arises: Does political action necessarily imply an oppositional relationship between the actors involved? Is the dichotomy between ' $\mathrm{We}^{\prime}$ and 'They' a necessary feature of the political domain? Could the political field be articulated based on agreement and consensus rather than on an adversarial and polemic logic? Could gaps between collective political identities be avoided? If so, through which strategies?

Irrespective of how we answer these questions, they refer to issues relevant to semiotics, the discipline that revolves around the study of meaning-making and signification (Hénault 2012; Landowski 2014; Fabbri 1998; Verón 1988; van Leeuwen 2005). On the one hand, due to social reality's intersubjective nature, semiotics constitutes a crucial standpoint for dealing with any type of social phenomena, most notably those grounded in interactions between social actors (both individual and collective) across different levels. On the other hand, in conducting any analysis of the social sphere, an interdisciplinary dialogue between semiotics and other research fields such as political and social theory is needed (van Leeuwen 2005; Lorusso 2010). Within the semiotic tradition, apart from Eliseo Verón, there have only recently been attempts to examine the political domain from a semiotic perspective (Landowski 2004, 2019; Cosenza 2018; Demuru and Albertini 2009). The interdisciplinary dialogue of semiotics with political and social theory (Selg and Ventsel 2020; Calil 2020; Moreno Barreneche 2020a) has reached a particularly productive point of articulation when it comes to the study of populism (Cervelli 2018; Landowski 2018; 2019; Sedda and Demuru 2018; Escudero Chauvel 2019, Moreno Barreneche 2019).

In line with these efforts, this article has three principal theoretical goals. First, it presents a general mapping of the political sphere studies carried out from a declared semiotic perspective, most notably those by Eric Landowski and Eliseo Verón. Furthermore, it aims to build bridges within the semiotic tradition, a field of research that unfortunately remains quite fragmented (Parra Ortiz 2020). Thirdly, it establishes a dialogue between political theory and semiotics by analyzing certain ideas belonging to the former whose semiotic nature has not been adequately examined, even if they have a clear discursive component. The works of Ernesto Laclau (1994, 2005) and Chantal Mouffe $(1993,2005,2013)$ will be crucial in this interdisciplinary dialogue. In contrast to their exclusively theoretical elaborations, however, semiotics aims to grasp meaning-making by studying diverse objects regarded as meaning manifestations (Land- 
owski 2014; Floch 1990). This empirical anchorage is what distinguishes a semiotic approach to the political from pure political theory: its specificity would then be given by studying meaning-making and signification within this social domain, based not on logical or theoretical deductions, but on the analysis of objects of diverse nature which are the carriers of meaning, such as speeches, advertisements, interactions, and practices, among many other articulations of the dimension of expression (Landowski 2019).

The article focuses on the dynamics of the discursive construction of collective identities within the political domain. This domain will be conceptualized as a set of semiotic practices (Fontanille 2008; Dondero 2017; Demuru 2017) by which individuals perform actions and interact with others to achieve specific goals on a discursive level; most crucially, to convince them of the value of their normative views regarding the exercise of power. Accordingly, we can conceive the political domain as a discursive field (Verón 1987) characterized by a "contest over meaning" (Pytlas 2016) between actors with conflicting interests. Representatives of the competing political projects attempt to 'fix meaning' for their views to prevail (De Cleen 2017) by employing discursive strategies to influence people's beliefs, emotions, and actions.

According to this logic, political identities should be conceptualized and studied as semiotic and discursive constructs linked to collective social actors. The latter consist of "imagined communities" (Anderson 1983), usually conceived as internally consistent and forming around a specific set of political interests and claims. Since the assumed uniqueness of every identity requires establishing relational differences with other identities (Arfuch 2005; Eco 2012; Escudero Chauvel 2005; Laclau 1994; 2005; Mouffe 2005), semiotics has much to say about the discursive construction of collective actors and identities (Eisenstadt 1998) through the employment of semiotic resources such as names, symbols, texts, colors, music, and general imagery. Shortly put, political identities, which are differential units representing different positions along the spectrum constituted by all the possible identities - to be found in the dimension of the content - , are in the first place segmented through opposition to other identities and subsequently brought into being. That is to say, they are articulated - and constructed through manipulation of the dimension of the expression. For semioticians, analyzing these empirically perceivable figurative manifestations unravels the underlying units of meaning constituting the multiple political identities at play.

To properly grasp the semiotic nature of collective identities, this article pays special attention to the role that the 'political gap': the space of indetermination between the various political identities locked in competition in the political 'contest over meaning' - plays in the construction of those identities and, consequently, in the articulation of the political as such. Here lies the most relevant contribution of this paper: demonstrating how social semiotics might help better understand the configuration of political identities that center around a We/They dichotomy by establishing a dialogue with 
other social sciences. Given that the distinction between collective political actors is constitutive of the political field (Schmitt 1932), it is proposed that gaps between identities are a necessary condition for the existence of the political as such. That is to say, the nature of the political domain requires a particular dynamics of identity construction that implicates the emergence of gaps and, along with them, of practices that might be detrimental to democracy, such as affective polarization and fanaticism. Although the emergence of identity gaps is unavoidable, how these gaps are made sense in various political interactions might take different forms (Mouffe 1993, 2005, 2013). We will return to this point in the third section, following the discussion of the aims, scope, and methods of social semiotics in the next section, and the subsequent conceptualization of the political domain from a meaning-making perspective.

\section{Aims, scope, and methods of social semiotics}

Contemporary semiotics stems from two scholarly traditions: a linguistic one, based on the work of Ferdinand de Saussure, and a philosophical one, based on the work of Charles Sanders Peirce. Starting from these different theoretical projects, two major approaches to semiotic research developed during the $20^{\text {th }}$ century (Traini 2006), their prominent representatives being Algirdas J. Greimas and Umberto Eco, respectively (Violi 2017). How can we formulate political semiotics based on these traditions? How should this field of research be apprehended and placed within the pre-existing semiotic tradition? Furthermore, what is distinctive about the semiotic approach to politics? What would be its theoretical premises, aims, and scope? Through which methods does it examine this discursive field? Given the current state of discord in semiotics, how can a researcher conceive semiotics' aims, scope, and methods?

To start with, the relatively recent consolidation of semiotics as a discipline largely explains the lack of consensus among semioticians regarding the scope of their research. As a result, the debate on semiotics' status - whether it be a discipline, theory, method, science, outlook, or perspective - is still alive, together with that concerning its descriptive or critical scope. Secondly, diverse theoretical approaches have arisen issued from philosophy (C. S. Peirce), structural linguistics (F. de Saussure, L. Hjelmslev, A. J. Greimas), functional linguistics (M. Halliday), cultural theory (J. Lotman), the production and circulation of social discourses (E. Verón), etc. As a result of semiotic paradigms' proliferation, researchers usually embed their work in any one of these without explaining the reasons for their choice.

According to Patrizia Violi (2017), the two major semiotic traditions - the 'generative' (Greimas) and the 'interpretative' (Eco) - share certain fundamental premises. Firstly, the assumption of a 'structural matrix' according to which meaning is either not 
given or is pre-existent, yet emerges from sets of relations and differences. This idea was initially introduced in linguistics by Ferdinand de Saussure (1916) and further developed by Louis Hjelmslev (1943). This premise brings to the fore the centrality of relations in studying meaning-making, including in the social realm. Similarly, in a recent book where they seek to open a fruitful dialogue between semiotics, political and social theory, Peeter Selg and Andreas Ventsel (2020) identify a common relational matrix between Lotman's cultural semiotics and Laclau's political theory. For Laclau, "there is no beyond the play of differences" as "elements do not pre-exist the relational complex but are constituted through it" (Laclau 2005: 68-69). According to him (2005: 68), under the guise of 'discourse,' one should seek to understand "any complex system of elements in which relations play the constitutive role." Selg and Ventsel highlight the relevance of considering 'relational sociology' when studying the social domain from a semiotic perspective. According to this recent social theory paradigm (Dépelteau 2018; Donati 2011; Emirbayer 1997), relations are constitutive of social reality and its entities. That is why 'relational thinking' and social semiotics share several premises and, hence, have much in common as theoretical projects (Moreno Barreneche 2020b)

Violi (2017) suggests that the generative and interpretative semiotic traditions alongside which one could certainly add Verón's discursive and Lotman's cultural approach - also share the premise of anti-essentialism. Rejecting any pre-social entities entails the constructivist view of social 'reality' as constructed through the multiple intersubjective negotiations of meaning in the production, circulation, and consumption of meaning (Verón 1988). As a result, within semiotics (and, more generally, constructivist social thought), the social field's nature is assumed to be discursive, i.e., based on relations and differences. This is an especially fruitful approach to studying political identities - particularly their construction and their inter-relations. Another point of agreement between the two semiotic traditions, according to Violi (2017), is the assumption of narrativity as an organizing principle of meaning and experience, a premise widely embraced by cognitive semiotics as well (Paolucci 2012).

In recent decades, semioticians have moved beyond their traditional focus on autonomous and closed texts (texts strictu sensu), on structures and systems, and broadened their research to encompass anything that is or can be meaningful (Landowski 2014; van Leeuwen 2005). This widening of scope has given place to 'social semiotics,' an approach with multiple representatives and practitioners worldwide, who agree on the basic premises presented above. The most prominent and influential researcher in this field is doubtlessly Eric Landowski, widely associated with the sociosémiotique. Aiming to develop an all-encompassing 'semiotics of experience,' Landowski extended Greimas' semiotic theory to the social sphere, studying a broad spectrum of objects, including the political dimension (Landowski 2004; 2019). Also, within French-speaking academia, Jean-Marie Floch (1990), Maria Giulia Dondero (2017), and Jacques Fontanille 
(2008) have proposed studying practices from a semiotic perspective. The latter developed a model consisting of six dimensions for studying semiotic phenomena, departing from the strict focus on signs and texts and including, among other elements, practices, strategies, and 'forms of life' (Fontanille 2015).

An alternative attempt to develop a 'social semiotics' we find in Robert Hodge and Günther Kress (1988: viii), for whom "meaning is produced and reproduced under specific social conditions, through specific material forms and agencies." This account was embraced and further developed by Theo van Leeuwen (2005), who established a fruitful dialogue with scholars working in critical discourse analysis. Additionally, with one foot in Latin America and the other in France, Eliseo Verón (1988) formulated a theory of social semiotics based on the study of social discourses. He is doubtlessly one of the pioneers of the semiotic analysis of the political field. Finally, special reference is also due to Juri Lotman (1990; 2009), who studied cultural phenomena from an innovative semiotic perspective and whose work has been extremely influential in many academic circles.

In summary, we can define social semiotics as the discipline, method, perspective, science, theory, or outlook interested in understanding the production of signification and meaning within the inter-discursive and inter-subjective networks that constitute the social realm (Verón 1989). In other words, it aims at grasping 'meaning in action,' i.e., how semiosis takes place dynamically in the many interactions, situations, practices, and other signifying processes that take place within the social domain, many of which are open and expansive in time (Landowski 2004, 2014; Lorusso 2010). This conception of semiotic research departs from the self-imposed restriction to texts with a high degree of closure and autonomy, as social semiotics seeks "to account for how sense emerges from daily life and lived experience with its many dimensions" (Landowski 2014: 10).

Semioticians seem to agree on two general premises regarding which methodology to employ in studying 'meaning in action.' On the one hand, the distinction between the dimensions of expression and content, derived from Hjelmslev's elaboration of Saussure's distinction between the 'signifier' and the 'signified' (Courtés 2007). Semiosis - semiotics' object of study (Verón 1988; Lorusso 2010) - refers to the arbitrary and culturally variable link between units belonging to these two dimensions. Namely, how any given content is expressed through articulating perceivable semiotic resources and vice-versa, how any given articulation on the expression dimension leads to the postulation of a unit of meaning in the content dimension (as in the case of political identities). Semiotics' inescapable empirical anchorage entails, therefore, the premise that to grasp meaning - especially 'meaning in action' - is only possible when looking at empirically perceivable 'semiotic objects,' broadly called 'texts' (Landowski 2014). Once identified and delimited by the researcher, these 'semiotic objects,' varying from speeches, having a clear beginning and end to open-ended situations, can be analyzed through the methodological distinction between expression and content. 


\section{The political as a social and discursive construction}

Eric Landowski (2019: 8) argues that the political field is constituted by multiple processes of construction, deconstruction, and reconstruction of 'rapports de sens' between social actors. These relations are dynamic, given that they are open and change over time. If social semiotics is interested in grasping signification and meaning within the social realm, then the political seems to be a suitable study object. Therefore, semioticians must construct the political as a semiotic object (Landwoski 2019). Yet, one must ask: What is specific of politics as a social field? What are the interactions and practices that characterize this domain? To answer these questions, there is a need for a dialogue with political theory. To start with, the signifier of 'politics' is problematic. It condenses and encompasses disparate actions and practices (Van Deth 2014), such as running for office, demonstrating or protesting, participating in party rallies, handling a country's external relations, or posting political content on social media (Theocharis 2015). Nevertheless, when speaking of 'politics' as a distinct social sphere, something is assumed to be equivalent in all of these actions.

Selg and Ventsel (2020) argue that the political comprises three main dimensions: power, governance, and democracy. This seems an appropriately analytical characterization of the field, which, from a semiotic perspective, can be conceived as an ensemble of practices and interactions aimed at conducting the everyday life of a group that is extended in time and takes place across multiple levels. This group can be a nationstate, a local community, or even a supra-national entity such as the European Union. As Walzer (1983: 62) argues, all of these are "ongoing associations of men and women with some special commitment to one another and some special sense of their common life." In the context of representative democracies, the principle of popular sovereignty (i.e., the will of the demos) remains the ground for the legitimate exercise of power in the form of governance. As a result, candidates and parties try to attract voters with their normative projects. From a semiotic perspective, politics can be conceived as the social field characterized by having power relations as its focal point (Landowski 2019).

In identifying the political as a social field, Chantal Mouffe (2005) distinguishes between accounts that perceive political activity as consensus-oriented and those highlighting its inescapable antagonistic character. Criticizing the former's naiveté, Mouffe argues that conflict and disagreement inhere within the political's core, an idea she borrows from Carl Schmitt. For Schmitt (1932), what distinguishes the political from other social domains is the opposition between 'friend' [Freund] and 'enemy' [Feind]. ${ }^{1}$ This results from different - and usually conflicting - alternatives of conducting the demos' common destiny.

1 Schmitt (1932: 17) specifies that the word 'Feind' ('enemy' or 'foe,' in English) is closer in meaning to the Latin word hostis than it is to inimicus. 
Mouffe establishes a distinction between the categories of 'politics' and 'the political,' with the former used to refer to the multiple practices that characterize politics as a social activity, while the latter encompasses an ontological conception of the political domain as "the very way in which society is instituted" (Mouffe 2005: 8-9). From a semiotic perspective, Landowski $(2004,2019)$ established a similar distinction between the categories of 'la politique' and 'le politique,' which translate as politics and the political, respectively. According to Landowski (2019: 7), the majority of the studies that have been conducted on the political field have dealt with specific discursive manifestations, such as the speeches of government officials, political campaigns, and other forms of political communication that pertain to the domain of politics. However, what matters for social semiotics is the political, i.e., the dynamics of meaning-making based on the interactional grammars enabling these communicational activities. Hence, a semiotic approach to the political is concerned with grasping the deep structures that articulate this field, such as Schmitt's friend / enemy dichotomy. According to Landowski (2019: 7), this task should lead to developing a model of the general syntax of power relations, capable of explaining in a systematic manner "the broad diversity of political regimes experienced or conceived across space and time."

If power and power relations define the political as a distinct social field, the 'contest over meaning' taking place in it is a discursive manifestation of a contest over power. In the latter context, both individual and collective political actors produce meaning-effects to influence other actors' will and actions in a way that aligns them with theirs. In a simple yes / no referendum, like those that Swiss citizens regularly face, political actors attempt to influence public opinion by deploying discursive devices to convince citizens to vote in line with their normative views. In other words, the goal of political action is to make others know, feel, believe, and do specific things. This demonstrates how within representative democracies, politics becomes an activity based on a manipulative regime of interaction, grounded on a principle of intentionality (Landowski 2019). Numerous aspects of this domain interest semiotics, such as the words and rhetorical games employed by political actors in public speeches, alongside the politicians' personas, styles, and body language in public appearances, the interactional dynamic in parliamentary debates, the traditions that emerge surrounding specific political events and actors, etc.

Another research field for semiotics is the study of the actors that constitute and reproduce the political realm. Who are the actors or subjects involved in this contest over meaning and power relations? One of the political's defining features is that interactions take the form of a confrontation between political identities articulated discursively, following a set of dynamics of a semiotic nature. These identities take the form of political parties, yet they also represent broader political ideologies, such as socialism and liberalism, or specific claims, such as feminism or environmentalism. Eliseo Verón (1989: 140), one of the pioneers in the semiotic study of the political domain, be- 
lieved that "the democratic political system is one of the fields for the management of social identities." Aligning with Schmitt's and Mouffe's proposal, he argued that the political takes the form of a 'struggle between enunciators' that makes political enunciation inherently polemic and "inseparable from the construction of an adversary" (Verón 1987: 16). From a semiotic perspective, this mechanism constitutes the foundation for the 'contest over meaning' that takes place on the political level and is characterized by the 'discursive games' played by the political actors.

Following the premises shared by the various semiotic traditions, the political domain is conceived as a space comprising specific types of enunciation, meaningful action, and interaction. This implicates a constructivist understanding of the political, according to which its 'reality' is not something given but constructed through multiple and heterogeneous instances of meaning negotiation between actors and grounded in specific beliefs and institutionalized codes regarding the conduct of power relations. As Verón (1988: 126) argues, meaning-making is the basis for the material organization of society, its institutions, and its social relations. The political is not an exception to this general principle.

The starting point of a semiotic study of political identities would be to identify the multiple collective actors (or the claims) that structure the public debate within a given political sphere. The most obvious material for this type of work would be to study how political parties and other actors (trade unions, guerrilla movements, etc.) represent themselves. This involves the study of programs, manifestos, propaganda, and other semiotic devices. These articulations, taking place in the expression dimension, enable us to identify the structures underlying the specific political identities' content dimension. In Spain's case, for example, following years of dominance of the Socialist Party (PSOE) and the Popular Party (PP) in the political landscape, there has been a recent emergence of new parties like Podemos, Ciudadanos, and Vox. For the electorate to find them identifiable, these parties had to construct their own identities using specific resources, including discursive strategies towards the traditional parties to justify their coming into being. As mentioned above, other political claims might also give rise to the emergence of collective identities even if they do not ultimately crystallize in political parties: feminism, the 'Fridays for Future' and 'Black Lives Matter' movements, the 'Madres de Plaza de Mayo' in Argentina, associations of local rural producers, amongst many others, also constitute cases of imagined groups united by specific normative views and shared political goals. Political identities are everywhere, whether in a structured and institutionalized manner or not. 


\section{The discursive construction of political identities and the necessity of the gap}

The previous section demonstrated why the political field is a good fit for social semiotics. In this final section, it is argued that the 'gap' between collective identities is an unavoidable feature of the constitution of the political. Before focusing on the gap, however, something must be said regarding the identities linked to the collective actors involved in the political 'contest over meaning.' This argument will be structured in three steps: (1) the polemic dynamics inherent to the political domain give place to a necessary emergence of identities that are collective and based on the equivalence of claims; (2) given that these identities transcend the individual dimension, they need to be constructed discursively (i.e., through the employment of semiotic resources that characterize and differentiate them from other collective identities); and (3) this discursive construction takes place by establishing a distinction from other collective identities. In conclusion, the gap seems to be unavoidable in the construction of the political.

If the political is a 'contest over meaning' in which political actors - such as candidates, parties, movements, and so on - struggle on a discursive level to make their normative views prevail, one could agree with Schmitt, Mouffe, and Verón that the political field has an inevitably adversative and polemic character. However, for the 'political pluriverse,' as Schmitt (1932: 41) calls it, to be manageable and understandable, it must comprise a reduced number of voices with their respective claims and demands. Schmitt (1932: 14) highlighted the importance of group formation in the constitution of the political because, in his view, the distinction between friend and enemy reflects the degree of the feasibility of a potential association (or not) with others. To ensure the manageability of the political sphere, individual demands must somehow be grouped, giving place to clusters of demands. This is how collective identities emerge: as Laclau argues (2005: ix), "the unity of the group is [...] the result of an articulation of demands."

Although this claim does not imply that every social group is political, according to Schmitt (1932: 25), "every religious, moral, economic, ethnic or other opposition transforms itself into a political one when it is strong enough as to effectively group individuals in friends and enemies." In this sense, how a specific topic or demand becomes a political issue is of utmost interest for a semiotic account due to every political process's evident dynamic character and publicity. As Glynos and Howarth (2007: 115) argue, political practices have "a distinctively public import."

Studying populism, Laclau (2005) argued that to transcend the individual or local dimension, demands must be structured around equivalences with other claims that are somewhat similar. This gives place to the emergence of a 'chain of equivalences' between collective actors and identities (i.e., units of meaning that transcend and en- 
compass the individuals who identify with them). Tags and categories like 'left-wing' and 'right-wing,' 'socialist' and 'liberal,' 'pro-globalization' and 'anti-globalization,' 'conservative' and 'progressive,' 'monarchist' and 'republican,' 'Republican' and 'Democrat,' 'feminist,' 'ecologist,' and 'animalist,' among others, fulfill this essential function of grouping political claims. As Verón (1989: 141) argues, political discourse is grounded in a "theory of articulation of differences", particularly in the recognition of these differences by the actors involved in the game. For Verón (1987: 17), this leads to the discursive construction in the sphere of political enunciation of collective actors, which according to him, are at least two in number: one positive, being based on a relation of identification that gives place to an "inclusive Us" - the "prodestinatario' ['proaddressee'] - and one negative, based on a relation of alterity and exclusion - the 'contradestinatario' ['counter-addressee']. These collective identities are traceable in the act of political enunciation. This mechanism occurs by drawing imaginary boundaries between various units structured around a sort of 'semiotic core,' consisting of a set of key beliefs, values, and principles.

A combination of concepts from Hjelmslev's structural linguistics and Lotman's cultural semiotics might help to understand this idea better. Based on de Saussure's work, Hjelmslev (1943) argued that a unit's meaning is always grounded in its relations with other units considered distinct from it. Following up on Hjelmslev, Umberto Eco (1976) argues that we must perceive meaning as a differential unit within a broader network. It is the product of a culturally grounded segmentation. This principle also applies to collective identities: What distinguishes one collective identity from another? Where are the boundaries of a given collective identity set? Who belongs to a collective identity and who does not?

These questions regarding the identities' content can be answered with Lotman's concept of the 'semiosphere.' He envisions a semiosphere as a bounded space with a core, within which meaning is made possible and circulates. What gives collective identities a differential value and, at the same time, identity is a set of elements identified as part of the core, together with those boundaries established imaginarily on a perceived distance regarding the core's components. Even if these boundaries are not clearly defined, elements - in this case, beliefs and normative views - are placed within the semiosphere, forming a hierarchy according to how close they are to the core. Thus, the boundaries will delimit the in-group from the out-group, making the latter foreign and, hence, a 'They' (Eisenstadt 1998; Tajfel 1982). In terms of Lotman's semiotics, these boundaries leave a space of untranslatability between the 'We' and 'They' semiospheres. In this essentially semiotic process, a gap is already visible.

The idea of setting boundaries between collective actors is also identified by Laclau (2005: 77) in his general account on the formation of collective identities. He argues that "the constitution of an internal frontier dividing society into two camps" is a necessary 
structural dimension for the emergence of populism, a phenomenon involving the discursive creation of a vague and unclearly delimited collective identity referred to as 'the people,' as opposed to the similarly collective identity of the 'no-people,' which might be projected onto an internal other, such as the elites or the ruling class, or an external one, such as the immigrants. In this sense, Laclau (2005: 67) considers populism as "the royal road to understanding something about the ontological constitution of the political as such." Collective identities - and among them political identities - are, then, discursive constructs emerging from the segmentation of the continuum of all the possible identities based on the establishment of an imaginary, contingent, and historically grounded boundary between 'We' and 'They.' This procedure implies a segmentation of the social by rendering individual and collective claims to be somehow equivalent.

After the boundaries of a political identity have been established around the core, the delimitation of a collective and inclusive ' $\mathrm{We}^{\prime}$ ' is only possible based on an opposition to a 'They' resulting from specific interactions (Eisenstadt 1998; Wendt 1992). Based on the processes of generalization and homogenization, the particular traits contained in the semiotic core of that identity are extended and imagined as being shared by every member. That is how the equivalences of the predicates of "being a socialist" or "being a feminist" with such and such traits, habits, and practices emerge. In this sense, these collective identities might even be conceived as 'forms of life' (Fontanille 2015). The 'They' necessary for the 'We' constitution is also postulated as a heterogeneous group whose existence is grounded in the general logical category of the 'Non-We,' in which everyone not identified as a member of the 'We' is placed. Hence, there is a process of 'inventing the enemy;' as Eco (2012: 2) argued, "having an enemy is important not only to define our identity but also to provide us with an obstacle against which to measure our system of values."

Once delimited, for these identities to become actors in the narrative plot (Paolucci 2012) of the political, they must somehow be expressed through articulating the expression dimension; they must be constructed discursively in the process of actorialization so that other social actors can perceive and recognize them. With this aim, names, logos, flags, songs, manifests, adverts, colors, practices, traditions, and numerous other 'semiotic resources' (van Leeuwen 2005), 'discursive devices' (Laclau 2005) or 'modes of sign production' (Eco 1976) are employed to bring into being the political collective identity that has been segmented and delimited as a distinct identity. Individuals can identify with the latter by recognizing the equivalence and/or coincidence of their political interests, values, preferences, and demands. Given that this construction involves articulating differences, exactly how identity becomes perceivable comprises a highly crucial aspect of its very existence. One could certainly imagine the challenges of brainstorming and devising the name of a new political group: Where does it come from? What are its connotations? How does it relate to local political history? Let alone 
the creation of its graphic and visual identity. The constructivist aspect of this process is evident.

It seems logical and necessary then that for collective identities to exist as differential units, distinct from one another, there is a need for the presence of an Other (even if in imaginary terms), whose whole (discursive) being is articulated around a semiotic core different from that of the 'We.' As Schmitt (1932) points out, it is on this Otherness [Anderssei] that the conflict with the Other [der Andere, der Fremde] is grounded. In the political domain, given that the Other is typically a collective actor, semiotic mechanisms must be activated to construct those identities to be recognizable by both the 'proaddressees' and the 'counter-addressees,' as identified by Verón. Therefore, the gap, i.e., this indetermination space, in which the political identities' boundaries might overlap and clash, seems to be unavoidable. By working as a sort of 'river' that divides a geographical region into two differentiated sides (the 'here' and 'there'), the gap makes identification with one or the other side ('We' and 'They') not only meaningful but also possible. Were there not a river, then this identification would not be possible, as there would be no material markers that could convey the distinction between sub-sections of that geographical region. Therefore, the gap seems to be a necessary condition for the emergence and the discursive construction of collective identities in the political domain, and with them, of the domain itself.

\section{Concluding remarks}

This article argues that the emergence of collective identities reflects the constructed and inter-subjective nature of the political field, one of the many discursive fields that constitute the social realm. Given that every identity is necessarily defined in relational terms and can only exist as a distinct unit of meaning by establishing differences with other identities, the We/They logic appears inevitable. This seems to be especially true for a domain whose defining feature, according to Schmitt (1932), is the opposition between the imagined groups of friends and enemies. Consequently, several dynamics will emerge that reflect a polemic and an adversative form. The gap can be conceived as a necessary yet unclearly delimited space of indetermination, in which a collective identity ends and the other begins. As mentioned previously, this seems to be an essential condition for the possibility of collective identities to exist within the social realm as meaningful categories. Therefore, semiotics can offer a broad conceptual and theoretical toolbox to understand better how these identities emerge and are invested with meaning so that individuals can identify with them. This article aimed to contribute to this direction; hence, it should be treated as a theoretical starting point for substantial productive empirical work. 
Besides the descriptive and analytical aspects of researching political identities, a key question for a semiotic approach to the political is normative. It concerns how to manage this necessary gap to avoid the emergence of affective polarization, extremism, fanaticism, and incivility. In open and democratic societies, it seems relevant to maintain the interactions and exchanges between political actors based on a rational dimension rather than on a passionate one, even if affect and emotions are constitutive of every identity (Tajfel 1982) and, more generally, of the public sphere (Peñamarín 2020). In acknowledging that affect plays a crucial role in the political, Mouffe (2005) distinguished between 'agonism' and 'antagonism' as the two possible forms of relationship between 'We' and 'They.' The former is based on the Other's conception as a legitimate adversary, disagreeing with whom takes the form of dialogue. The latter involves the Other's conception as an enemy that must be eliminated. The dangerous effects of this gap fall within the latter's domain.

The so-called 'mediatization of politics' (Verón 1998; Mazzoleni and Schulz 1999; Esser and Strömbäck 2014) induced the strengthening and mainstreaming of the antagonistic mode; consequently, it has led to increased polarization, over-simplification of social reality, and the Other's assessment in moral rather than political terms (Cosenza 2018; Mouffe 2005; Moreno Barreneche 2020c). In recognizing a political Other as a distinct and competing collective identity, there is a tendency to engage in its immediate axiologization in negative terms, turning it into an enemy instead of an Other with whom the social space might be shared, despite disagreements on issues that are constitutive of those identities. More importantly, the Other is frequently neglected as an interlocutor with whom the 'We' could enter into dialogue to achieve some sort of consensus on a broad array of issues. Even if collective identities require constitutive differences to come into being, this does not necessarily exclude the possibility of achieving consensus. This begs a series of questions: What strategies, then, should we employ to avoid an immediate axiologization of the Other? Which discursive mechanisms should be avoided and which fostered? How has the mediatization of politics contributed to the normalization of antagonistic practices? Questions like these once again bring to the fore the centrality of social semiotics as a discipline that, besides its descriptive aims anchored in the empirical examination of social practices and situations, has an underlying transformative scope that is intrinsically political (Landowski 2019). 


\section{Bibliography}

Arfuch, Leonor (ed.) 2005. Identidades, sujetos, subjetividades. Buenos Aires: Prometeo. Anderson, Benedict 1983. Imagined Communities. London: Verso.

Calil, Lucas 2020. Semiótica das estruturas sociais. Estudos semióticos 16 (2): 56-80.

Cervelli, Pierluigi 2018. La comunicazione politica populista: corpo, linguaggio e pratiche di interazione. Actes sémiotiques 121.

Cosenza, Giovanna 2018. Semiotica e comunicazione politica. Bari/Rome: Laterza.

Courtés, Joseph 2007. La sémiotique du langage. Paris: Armand Collins.

De Cleen, Benjamin 2017. Populism and Nationalism. In: Cristóbal Rovira Kaltwasser et al. (eds.) The Oxford Handbook of Populism. Oxford: Oxford University Press.

De Saussure, Ferdinand 1916. Course de linguistique générale. Paris: Payot.

Demuru, Paolo 2017. Praticas de vida. Entre semiótica, comunicação e política. Estudos semióticos 13 (1): 28-39.

Demuru, Paolo and Matteo Albertini 2009. La politica come semiosfera e la costruzione 'in campo' dell' identità. Il caso del Partito Democratico. Versus 107-108: 101-117.

Dépelteau, François 2018. Relational Thinking in Sociology: Relevance, Concurrence and Dissonance. In: François Dépelteau (ed.) The Palgrave Handbook of Relational Sociology. Cham: Palgrave Macmillan.

Donati, Pierpaolo 2011. Relational Sociology. A New Paradigm for the Social Sciences. London: Routledge.

Dondero, Maria Giulia 2017. Du texte à la pratique: Pour une sémiotique expérimentale. Semiotica 219: 335-356.

Eco, Umberto 1976. A Theory of Semiotics. Bloomington: Indiana University Press.

Eco, Umberto 2012. Inventing the Enemy and Other Occasional Writings. Boston/New York: Houghton, Mifflin \& Harcourt.

Eisenstadt, Shmuel N. 1998. Modernity and the Construction of Collective Identities. International Journal of Comparative Sociology 39 (3): 138-158.

Emirbayer, Mustafa 1997. Manifesto for a Relational Sociology. American Journal of Sociology 103 (2): 281-317

Escudero Chauvel, Lucrecia 2005. Identidad e identidades. Estudios 17: 51-57.

Escudero Chauvel, Lucrecia 2019. El pueblo de la web. Consecuencias de la mediatización y transformación de la esfera política. DeSignis 31: 209-240.

Esser, Frank and Jesper Strömbäck (eds.) 2014. Mediatization of Politics. Basingstoke: Palgrave Macmillan.

Fabbri, Paolo 1998. La svolta semiotica. Bari/Rome: Laterza.

Floch, Jean-Marie 1990. Sémiotique, marketing et communication. Paris: Presses Universitaires de France.

Fontanille, Jacques 2008. Pratiques sémiotiques. Paris: Presses Universitaires de France.

Fontanille, Jacques. 2015. Formes de vie. Liége: Presses Universitaires de Liége. 
Glynos, Jason and David J. Howarth 2007. Logics of Critical Explanation in Social and Political Theory. London: Routledge.

Hénault, Anne 2012. Les enjeux de la sémiotique. Paris: Presses Universitaires de France. Hodge, Robert and Günther Kress. 1988. Social Semiotics. Ithaca: Cornell University Press.

Hjelmslev, Louis 1943. Prolegomena to a Theory of Language. Wisconsin: Wisconsin University Press.

Iyengar, Shanto, Gaurav Sood and Yphtach Lelkes 2012. Affect, Not Ideology. A Social Identity Perspective on Polarization. Public Opinion Quarterly 76 (3): 405-431.

Laclau, Ernesto (ed.) 1994. The Making of Political Identities. London: Verso.

Laclau, Ernesto 2005. On Populist Reason. London: Verso.

Landowski, Eric 2004. Passions sans nom. Paris: Presses Universitaires de France.

Landowski, Eric 2014. Sociossemiótica: uma teoria geral do sentido. Galáxia 27: 10-20.

Landowski, Eric 2018. Populisme et esthésie. Présentation. Actes Sémiotiques 121.

Landowski, Eric 2019. Politiques de la sémiotique. Rivista Italiana di Filosofia del Linguaggio 13 (2): 6-25.

Lorusso, Anna Maria 2010. Semiotica della cultura. Bari/ Rome: Laterza.

Lotman, Yuri 1990. Universe of the Mind. A Semiotic Theory of Culture. London: Bloomsbury.

Lotman, Yuri 2009. Culture and Explosion. New York: De Gruyer.

Mazzoleni, Gianpietro and Winfred Schulz 1999. 'Mediatization' of Politics: A Challenge for Democracy? Political Communication 16 (3): 247-261.

Mouffe, Chantal 1993. The Return of the Political. London: Verso.

Mouffe, Chantal 2005. On the Political. London: Routledge.

Mouffe, Chantal 2013. Agonistics. Thinking the World Politically. London: Verso.

Moreno Barreneche, Sebastián 2019. La definición de 'populismo': ¿qué puede aportar la semiótica? DeSignis 31: 69-79.

Moreno Barreneche, Sebastián 2020a. La democracia y sus otros. Una contribución desde la semiótica al debate sobre la erosión democrática. Revista de Estudios Sociales 74: 12-22.

Moreno Barreneche, Sebastián 2020b. Sentido, relaciones e interacciones. Intersecciones entre el pensamiento relacional y la sociosemiótica. Andamios 44.

Moreno Barreneche, Sebastián 2020c. Polarización política y fanatismo 'blando': una hipótesis semiótica. DeSignis 33: 143-158.

Paolucci, Claudio 2012. Sens et cognition: La narrativité entre sémiotique et sciences cognitive. Signata 3: 299-316.

Pariser, Eli 2012. The Filter Bubble. What the Internet Is Hiding from You. London: Penguin.

Parra Ortiz, Elizabeth 2020. ¿Por qué es necesaria una historia de la semiótica? En busca de la identidad y la memoria a reconstruir. CIC. Cuadernos de Información y Comunicación 25: 47-60. 
Peñamarín, Cristina 2020. Fronteras afectivas de la esfera pública y semiótica pragmática. CIC. Cuadernos de Información y Comunicación 25: 61-75

Pytlas, Bartek 2016. Radical Right Parties in Central and Eastern Europe. London: Routledge.

Recuero, Raquel 2015. Social Media \& Symbolic Violence. Social Media+Society 1 (1): 1-3. Rogowski, Jon and Joseph Sutherland 2016. How Ideology Fuels Affective Polarization. Political Behavior 38: 485-508.

Schmitt, Carl 1932. Der Begriff des Politischen. Munich: Duncker \& Humblot.

Sedda, Franciscu and Paolo Demuru 2018. Da cosa si riconosce il populismo. Ipotesi semiopolitiche. Actes Sémiotiques 121.

Selg, Peeter and Andreas Ventsel 2020. Introducing Relational Political Analysis. London: Palgrave.

Tajfel, Henri 1982. Social Psychology of Intergroup Relations. Annual Review of Psychology 33: 1-39.

Theocharis, Yannis 2015. The Conceptualization of Digitally Networked Participation. Social Media+Society 1 (2): 1-14.

Traini, Stefano 2006. Le due via della semiotica. Milano: Bompiani.

Van Deth, Jan 2014. A Conceptual Map of Political Participation. Acta Politica 49: 349367.

Van Leeuwen, Theo 2005. Introducing Social Semiotics. London: Routledge.

Verón, Eliseo 1987. La palabra adversativa. Observaciones sobre la enunciación política. In: Eliseo Verón et al. (eds.) El discurso político. Lenguajes y acontecimientos. Buenos Aires: Hachette.

Verón, Eliseo 1988. La semiosis social. Barcelona: Gedisa.

Verón, Eliseo 1989. Semiótica y teoría de la democracia. Revista de Occidente 92: 130-142.

Verón, Eliseo 1998. Mediatización de lo político. Estrategias, actores y construcción de los colectivos. In: G. Gauthier, A. Gosselin y J. Mouchon (eds.) Comunicación y política. Barcelona: Gedisa.

Violi, Patrizia 2017. Due vie per la semiotica o un incrocio di sguardi? Algirdas Greimas e Umberto Eco a confronto. Entornos 30 (1): 25-33.

Walzer, Michael 1983. Spheres of Justice. New York: Basic Books.

Wendt, Alexander 1992. Anarchy is what Stakes Make of it: The Social Construction of Power Politics. International Organization 46 (2): 391-425.

AUTHOR

Sebastián Moreno Barreneche Lecturer, Faculty of Management and Social Sciences, Universidad ORT Uruguay, Montevideo, Uruguay. 


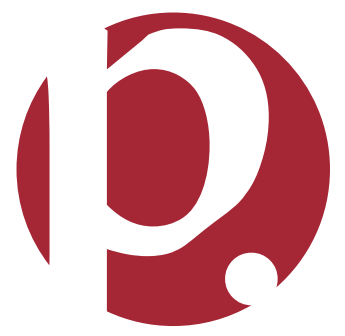

